Journal of Clinical Investigation
Vol. 43, No. 2, 1964

\title{
Calorigenic Effect of Norepinephrine Correlated with Plasma Free Fatty Acid Turnover and Oxidation*
}

\author{
Daniel Steinberg, Paul J. Nestel, $\dagger$ Elsworth R. Buskirk, $\ddagger$ and \\ RONALD H. THOM PSON \\ (From the Laboratory of Metabolism, National Heart Institute, and the Metabolic Disease \\ Branch, National Institute of Arthritis and Metabolic Diseases, Bethesda, Md.)
}

The increase in oxygen consumption caused by administration of epinephrine has been extensively studied in animals and in man. Many physiological and biochemical correlations have been made and many different hypotheses have been advanced to explain this so-called calorigenic effect, but there is still no clearly established consensus regarding the mechanism or mechanisms involved $(1,2)$.

In recent years it has become clear that one of the most striking metabolic effects of the catecholamines is their ability to stimulate mobilization of depot fat in the form of free fatty acids (FFA) (3). Studies by Fritz, Davis, Holtrop, and Dundee (4) and by Eaton and Steinberg (5) have shown, moreover, that the rate of oxidation of labeled FFA by isolated skeletal muscle preparations in vitro is a function of the concentration of FFA in the medium. Similar effects of FFA concentration on FFA oxidation have been demonstrated in rat liver slices (6) and in perfused rat liver (7). We have previously suggested, therefore, that the calorigenic action of catecholamines might be due, at least in part, to their effect in mobilizing FFA (5).

The present clinical studies were undertaken to explore this possibility further. Because the metabolic effects of epinephrine are somewhat more complex than those of norepinephrine, in that the former actively mobilizes glucose as well as FFA, the present studies were done primarily with norepinephrine. It is shown that infusion of norepinephrine increases the rate of oxygen

* Submitted for publication August 12, 1963; accepted October 3, 1963.

† Present address: Department of Medicine, Royal Melbourne Hospital, Melbourne, Australia.

$\ddagger$ Present address: Laboratory of Applied Physiology, Pennsylvania State University, State College, University Park, Pa. consumption in man and that this is accompanied by an increase in turnover of plasma FFA and an increase in rate of conversion of labeled plasma FFA to respiratory $\mathrm{C}^{14} \mathrm{O}_{2}$. All of these effects of norepinephrine are abolished or radically reduced when the patient has first been given an intravenous dose of pronethalol [2-isopropylamino1-(2-naphthyl)ethanol hydrochloride], a drug that inhibits catecholamine stimulation of adrenergic $\beta$-receptors $(8,9)$ and that prevents the FFA mobilization induced by catecholamines (10). ${ }^{1} \mathrm{~A}$ preliminary report of these findings has been made (11).

\section{Methods}

The subjects studied were young, adult, normal, control volunteers on regular ward diets, with their total caloric intake adjusted to maintain constant body weight. Metabolic studies were all done after a 12- to 16-hour fast, and subjects remained at rest in bed on the mornings of studies. Indwelling plastic catheters were placed in an antecubital vein of each arm after the skin had been anesthetized with Xylocaine (2-diethylamino-2',6'-acetoxylidide). A slow drip of $0.85 \% \mathrm{NaCl}$ was maintained to keep the catheters open. The subjects were then taken to the metabolic chamber in a wheel chair. The construction and operation of the metabolic chamber have been fully described by Buskirk, Thompson, Moore, and Whedon (12). At least 30 minutes was allowed to establish stable control values for rate of oxygen consumption. Blood samples were drawn from one arm through a 3-way stopcock and delivered into a chilled tube containing heparin. Infusions of drugs, or labeled palmitate, or both, were given into the opposite arm with Bowman finger pumps.

Plasma FFA were determined by Dole's method (13) using isoöctane (2,2,4-trimethylpentane) in place of hep-

1 Since these studies were completed, the Research Department of Imperial Chemical Industries, Ltd., Macclesfield, England, manufacturers of pronethalol (Alderlin), has found that mice on chronic high dosage show a significant incidence of locally malignant lymphosarcomata of the thymus gland. Further use of the drug in clinical investigation should probably await thorough eva'uation of these preliminary findings. 
TABLE I

Effects of infused norepinephrine on FFA levels, FFA turnover, and oxygen consumption in normal control subjects

\begin{tabular}{|c|c|c|c|c|c|c|c|c|c|}
\hline $\begin{array}{c}\text { Subject, } \\
\text { sex, age, } \\
\text { wt }\end{array}$ & $\begin{array}{c}\text { Norepine } \\
\text { administ } \\
\text { Dosage } \\
\text { rate }\end{array}$ & $\begin{array}{l}\text { ephrine } \\
\text { tration } \\
\text { Time* }\end{array}$ & $\begin{array}{c}\text { Blood } \\
\text { pressure }\end{array}$ & $\begin{array}{l}\text { Pulse } \\
\text { rate }\end{array}$ & $\begin{array}{l}\text { Plasma } \\
\text { FFA } \\
\text { concen- } \\
\text { tration }\end{array}$ & $\begin{array}{c}\text { Plasma } \\
\text { FFA } \\
\text { turn- } \\
\text { over }\end{array}$ & $\begin{array}{c}\text { Percentage } \\
\text { change in } \\
\text { FFA } \\
\text { turnover }\end{array}$ & $\begin{array}{c}\mathrm{O}_{2} \\
\text { con- } \\
\text { sump- } \\
\text { tion }\end{array}$ & $\begin{array}{c}\text { Percentage } \\
\text { change in } \\
\mathrm{O}_{2} \text { con- } \\
\text { sumption }\end{array}$ \\
\hline \multirow{6}{*}{$\begin{array}{l}\text { C.H. (I), } \\
\text { M, 21, } \\
66.6 \mathrm{~kg}\end{array}$} & \multirow{2}{*}{\multicolumn{2}{|c|}{$\begin{array}{c}\mu g / \min \min \\
\text { Control values }\end{array}$}} & $m m H_{g}$ & & $\mu E q / m l$ & $\mu E q / \min$ & $\%$ & $m l / \min$ & $\%$ \\
\hline & & & $100 / 70$ & 60 & 0.69 & 326 & & 225 & \\
\hline & 6 & 12 & $118 / 85$ & 47 & 0.85 & 459 & +41 & 245 & +9 \\
\hline & 6 & 22 & & & 1.14 & 533 & +64 & 255 & +13 \\
\hline & 12 & 15 & $130 / 90$ & 45 & 1.29 & 544 & +66 & 245 & +9 \\
\hline & 12 & 26 & & & 1.38 & 540 & +66 & 265 & +18 \\
\hline \multirow{4}{*}{$\begin{array}{c}\text { C.H. (II), } \\
\text { M, 21, } \\
66.6 \mathrm{~kg}\end{array}$} & \multicolumn{2}{|c|}{$\begin{array}{l}\text { Control values } \\
\text { Placebo }\end{array}$} & $95 / 65$ & 70 & 0.36 & & & 215 & \\
\hline & \multirow{2}{*}{\multicolumn{2}{|c|}{$\begin{array}{l}\text { infusiont } 10 \\
\text { Control values }\end{array}$}} & $90 / 65$ & 55 & 0.33 & & & 210 & -2 \\
\hline & & & & & 0.46 & & & 211 & \\
\hline & 12 & 10 & $130 / 90$ & 47 & 0.93 & & & 235 & +11 \\
\hline \multirow{5}{*}{$\begin{array}{l}\text { B.L., } \\
\text { M, 23, } \\
66.1 \mathrm{~kg}\end{array}$} & \multicolumn{2}{|c|}{ Control values } & $100 / 60$ & 55 & 0.46 & & & 205 & \\
\hline & 10.5 & 15 & $110 / 80$ & 48 & 1.16 & & & 221 & +8 \\
\hline & \multicolumn{2}{|c|}{ Control values $\ddagger$} & $105 / 60$ & 47 & 0.54 & & & 205 & \\
\hline & 10.5 & 16 & $120 / 80$ & 47 & 1.42 & & & 229 & +12 \\
\hline & \multicolumn{2}{|c|}{ Control values } & $110 / 65$ & 58 & 0.48 & 226 & & 192 & \\
\hline B.L., & 6 & 10 & $115 / 80$ & 48 & 0.69 & 280 & +24 & 202 & +5 \\
\hline M, 23. & 6 & 27 & & & 1.65 & 677 & +200 & 210 & +9 \\
\hline \multirow[t]{2}{*}{$66.1 \mathrm{~kg}$} & 12 & 22 & $124 / 84$ & 46 & 1.61 & 573 & +154 & 231 & +20 \\
\hline & 20 & 18 & $150 / 90$ & 50 & 1.81 & & & 250 & +30 \\
\hline \multicolumn{10}{|l|}{ L.C., } \\
\hline M, 25, & \multicolumn{2}{|c|}{ Control values } & $100 / 76$ & 60 & 0.90 & 333 & & 235 & \\
\hline $72.6 \mathrm{~kg}$ & 18 & 16 & $140 / 110$ & 60 & 1.57 & 506 & +52 & 286 & +22 \\
\hline \multirow{4}{*}{$\begin{array}{l}\text { S.P., } \\
\text { F, 17, } \\
60.3 \mathrm{~kg}\end{array}$} & \multicolumn{2}{|c|}{ Control values } & $90 / 60$ & 50 & 0.39 & & & 155 & \\
\hline & 7.2 & 13 & $100 / 70$ & 48 & 1.21 & & & 165 & +6 \\
\hline & 14.4 & 14 & & & 1.69 & & & 181 & +17 \\
\hline & 14.4 & 25 & $120 / 80$ & 60 & 1.82 & & & 180 & +16 \\
\hline
\end{tabular}

* Times indicate the cumulative number of minutes from the start of administration at each dosage rate. Except where indicated by intervening control values, dosage rates were changed without interrupting the infusion.

† Saline infused by Bowman pump with identical routine of blood pressure readings and blood samplings that accompanied norepinephrine infusions. Infusion identified to patient as "norepinephrine."

$\ddagger$ Obtained 53 minutes after discontinuing first norepinephrine infusion.

tane. Blood glucose was measured enzymatically by the glucose oxidase method described by Keston (14). Reagents (Glucostat) were obtained commercially. ${ }^{2}$ Plasma lactate levels were determined enzymatically (15).

Plasma FFA turnover was determined by using a constant intravenous infusion of palmitate-1- $\mathrm{C}^{\mathbf{1 4}}$. The basis for this method has been fully discussed by Armstrong and associates (16). The infusion solution was prepared by adding a tracer amount of sodium palmitate-1- $\mathrm{C}^{14}$ to a solution of human serum albumin ( 5 to $7.5 \%$ ). The solutions were prepared for clinical use and were tested for sterility and absence of pyrogens. ${ }^{3}$ The labeled palmitate was diluted in 100 to $150 \mathrm{ml}$ of $0.85 \% \mathrm{NaCl}$ and infused at a rate of 1 to $1.5 \mathrm{ml}$ per minute. Within 15 to 20 minutes the total FFA radioactivity per milliliter of plasma had reached a plateau value that did not then vary more than $\pm 10 \%$ during the control period. Plasma FFA radioactivity was measured by first ex-

${ }^{2}$ Worthington Biochemical Corp., Freehold, N. J.

3 Performed by Mr. William H. Briner, Radiopharmaceutical Service, National Institutes of Health, Bethesda, Md. tracting by Dole's method, re-extracting the F-FA from the isoöctane layer into alcoholic $\mathrm{KOH}$, acidifying the latter, and finally re-extracting the FFA into isoöctane. The isoöctane was dried in a counting vial under a stream of $\mathrm{N}_{2}$, the residue was redissolved in toluene containing $0.5 \%$ 2,5-diphenyloxazole, and radioactivity was assayed in a Packard Tri-Carb liquid scintillation spectrometer. ${ }^{4}$ In several experiments the lipids in the final isoöctane extract were fractionated on silicic acid columns (17). No significant amounts of radioactivity were recovered with the phospholipid fraction.

For measurement of $\mathrm{C}^{14} \mathrm{O}_{2}$ production, a measured fraction of the gas stream from the metabolic chamber was diverted and collected in 4- to 5-minute periods in Douglas bags. The gas from these bags was slowly pulled through a gas-flow meter and delivered through a sintered glass diffuser into a column of $\mathrm{NaOH}$. A $\mathrm{Ba}(\mathrm{OH})_{2}$ trap connected in series showed that collection of $\mathrm{CO}_{2}$ was complete. Three-ml samples of the $\mathrm{NaOH}$ were added to $1 \mathrm{~g}$ of fluorescence-grade anthracene, ${ }^{5}$ and

4 Packard Instrument Co., La Grange, Ill.

5 Distillation Products, Inc., Rochester, N. Y. 
radioactivity was assayed in the liquid scintillation spectrometer (18).

Pronethalol (Alderlin) was generously donated. ${ }^{6}$ Norepinephrine (Levophed) was diluted in $0.85 \% \mathrm{NaCl}$ to a final concentration of $6.6 \mu \mathrm{g}$ per $\mathrm{ml}$ (expressed as the base).

\section{Results}

The changes in blood pressure, pulse rate, FFA concentration, and oxygen consumption produced

${ }^{6}$ Ayerst Laboratories, New York, N. Y. by intravenous infusion of norepinephrine are summarized in Tables I and II. In Table II the responses to a second norepinephrine infusion, given immediately after administration of pronethalol, are shown for ready comparison with the responses in the control state. The effects of norepinephrine in the control state will be discussed first.

Oxygen consumption. In every case infusion of norepinephrine at dosage rates of 10 to $21 \mu \mathrm{g}$

TABLE II

Blocking effect of pronethalol on the increased FFA turnover and hypermetabolism induced by norepinephrine

\begin{tabular}{|c|c|c|c|c|c|c|c|c|c|}
\hline $\begin{array}{c}\text { Subject, } \\
\text { sex, age, } \\
\text { wt }\end{array}$ & $\begin{array}{l}\text { Norepine } \\
\text { administ } \\
\text { Dosage } \\
\text { rate } T\end{array}$ & $\begin{array}{l}\text { nephrine } \\
\text { stration } \\
\text { Time* }\end{array}$ & $\begin{array}{l}\text { Blood } \\
\text { pressure }\end{array}$ & $\begin{array}{l}\text { Pulse } \\
\text { rate }\end{array}$ & $\begin{array}{c}\text { Plasma } \\
\text { FFA } \\
\text { concen- } \\
\text { tration }\end{array}$ & $\begin{array}{c}\text { Plasma } \\
\text { FFA } \\
\text { turn- } \\
\text { over }\end{array}$ & $\begin{array}{c}\text { Percentage } \\
\text { change in } \\
\text { FFA } \\
\text { turnover }\end{array}$ & 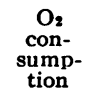 & $\begin{array}{l}\text { Percentage } \\
\text { change in } \\
\mathrm{O}_{2} \text { con- } \\
\text { sumption }\end{array}$ \\
\hline \multirow{10}{*}{$\begin{array}{l}\text { W.S., } \\
\text { M, 23, } \\
65.1 \mathrm{~kg}\end{array}$} & $\mu g / \min$ & $\min$ & $m m H_{g}$ & & $\mu E q / m l$ & $\mu E q / \min$ & $\%$ & $m l / \min$ & $\%$ \\
\hline & \multirow{2}{*}{\multicolumn{2}{|c|}{$\begin{array}{l}\text { Before pronethalol } \\
\text { Control values }\end{array}$}} & & & & & & & \\
\hline & & & $110 / 65$ & 74 & 0.69 & 420 & & 220 & \\
\hline & 18 & 12 & $140 / 85$ & 52 & 0.86 & 500 & +19.0 & 246 & +11.8 \\
\hline & 18 & 16 & & & & & & & \\
\hline & \multicolumn{2}{|r|}{$\begin{array}{c}16 \\
+2 \dagger\end{array}$} & & & 1.36 & 790 & +135.5 & 262 & +19.1 \\
\hline & \multicolumn{2}{|c|}{ After pronethalol } & & & & & & & \\
\hline & \multicolumn{2}{|c|}{ Control values } & $110 / 75$ & 70 & 0.86 & 430 & & 235 & \\
\hline & 18 & 8 & & & 0.73 & 430 & 0.0 & 197 & -16.2 \\
\hline & 18 & 16 & $142 / 90$ & 50 & 0.69 & 400 & -7.0 & 230 & -2.1 \\
\hline \multirow{8}{*}{$\begin{array}{l}\text { D.C., } \\
\text { M, 27, } \\
79.1 \mathrm{~kg}\end{array}$} & \multicolumn{2}{|c|}{ Before pronethalol } & & & & & & & \\
\hline & \multicolumn{2}{|c|}{ Control values } & $96 / 64$ & 75 & 0.37 & 258 & & 247 & \\
\hline & 10 & 15 & $150 / 100$ & 85 & 0.90 & 444 & +72.0 & 344 & +39.2 \\
\hline & \multirow{2}{*}{\multicolumn{2}{|c|}{$\begin{array}{l}\text { After pronethalol } \\
\text { Control values }\end{array}$}} & & & & & & & \\
\hline & & & $95 / 58$ & 72 & 0.39 & 298 & & 274 & \\
\hline & 10 & 7 & $115 / 80$ & 43 & 0.41 & 172 & -42.3 & 260 & -5.1 \\
\hline & 10 & 9 & & & & & & 220 & -19.7 \\
\hline & 10 & 15 & $130 / 85$ & 48 & 0.64 & 302 & +1.3 & 295 & +7.7 \\
\hline \multirow{8}{*}{$\begin{array}{l}\text { B.L. }(1), \ddagger \\
\text { M, 23, } \\
66.1 \mathrm{~kg}\end{array}$} & \multirow{2}{*}{\multicolumn{2}{|c|}{$\begin{array}{l}\text { Before pronethalol } \\
\text { Control values }\end{array}$}} & & & & & & & \\
\hline & & & $110 / 68$ & 55 & 0.70 & 270 & & 205 & \\
\hline & 16 & 12 & $140 / 95$ & 42 & 1.05 & 300 & +11.1 & 256 & +24.8 \\
\hline & \multicolumn{2}{|c|}{ After pronethalol } & & & & & & & \\
\hline & \multicolumn{2}{|c|}{ Control values } & $112 / 60$ & 59 & 0.68 & 270 & & 184 & \\
\hline & 16 & 11 & $140 / 100$ & 37 & 0.64 & 190 & -29.6 & 156 & -15.2 \\
\hline & \multicolumn{2}{|c|}{ Control values§ } & $118 / 58$ & 65 & 0.68 & 270 & & 215 & \\
\hline & 16 & 9 & $140 / 105$ & 38 & 0.59 & & & 140 & -23.9 \\
\hline \multirow{7}{*}{$\begin{array}{l}\text { R.B., } \\
\text { M. 35, } \\
86.4 \mathrm{~kg}\end{array}$} & \multicolumn{2}{|c|}{ Before pronethalol } & & & & & & & \\
\hline & \multicolumn{2}{|c|}{ Control values } & $100 / 68$ & 77 & 0.86 & 450 & & 215 & \\
\hline & 13 & 18 & $125 / 90$ & 55 & 1.13 & 588 & +30.7 & 235 & +9.3 \\
\hline & 21 & 14 & $140 / 105$ & 45 & 1.34 & 572 & +27.4 & 245 & +13.9 \\
\hline & \multicolumn{2}{|c|}{ After pronethalol } & & & & & & & \\
\hline & \multicolumn{2}{|c|}{ Control values } & $110 / 68$ & 83 & 0.86 & 460 & & 229 & \\
\hline & 21 & 14 & $140 / 90$ & 44 & 0.69 & 298 & -35.2 & 221 & -3.5 \\
\hline \multirow{5}{*}{$\begin{array}{c}\text { B.L. (II), } \\
\text { M, 23, } \\
66.1 \mathrm{~kg}\end{array}$} & \multicolumn{2}{|c|}{$\begin{array}{l}\text { Before pronethalol } \\
\text { Control values }\end{array}$} & $110 / 60$ & 78 & 0.52 & & & 240 & \\
\hline & $\begin{array}{c}18 \\
\text { After prone }\end{array}$ & $\begin{array}{l}13 \\
\text { 1ethalol }\end{array}$ & $155 / 83$ & 57 & 1.16 & & & 306 & +27.5 \\
\hline & \multicolumn{2}{|c|}{$\begin{array}{l}\text { After pronethalol } \\
\text { Control values }\end{array}$} & & & 0.85 & & & 236 & \\
\hline & 18 & 7 & $160 / 90$ & 45 & 0.56 & & & 208 & -12.6 \\
\hline & 18 & 14 & & & 0.68 & & & 229 & -3.8 \\
\hline
\end{tabular}

* Times indicate cumulative number of minutes from start of infusion at each dosage rate. Dosage rates were changed without interrupting the infusion.

$\uparrow$ Values determined 2 minutes after discontinuing the norepinephrine infusion.

Complete record for this study shown in Figure 1 .

Control values obtained 29 minutes after discontinuing first infusion of norepinephrine. 
per minute ( 0.13 to $0.31 \mu \mathrm{g}$ per $\mathrm{kg}$ per minute) significantly increased the rate of oxygen consumption. The value at the peak of the response, reached toward the end of the 15- to 25-minute infusion period, was $21 \pm 8 \%$ above control values ( 11 cases shown in Tables I and II). The responses ranged from +11 to $+39 \%$.

FFA levels and turnover. Basal FFA levels in the plasma, determined after the subjects were in position in the metabolic chamber and just before the norepinephrine infusion was started, were $0.58 \pm 0.19 \mu \mathrm{Eq}$ per $\mathrm{ml}$. At the time when the maximal response in oxygen consumption was reached, FFA levels had risen to $1.28 \pm 0.27 \mu \mathrm{Eq}$ per $\mathrm{ml}$, an increase of $127 \pm 57 \%$ over basal values.

In seven subjects FFA turnover was determined before and during norepinephrine treatment by using a continuous intravenous infusion of palmitate-1-C $\mathrm{C}^{14}$. In every case norepinephrine caused an increase in turnover, but the response was variable, ranging from 11 to $154 \%$ above control values with a mean rise of $74 \pm$ 53\% (Tables I and II). The percentage increase in FFA turnover was greater than the percentage increase in oxygen consumption in six of the seven cases. The mean percentage increase in FFA turnover for the seven cases studied $(74 \%)$ was more than three times the mean percentage increase in oxygen consumption (24\%).

Pulse and blood pressure. Within a minute or two after the infusion was started, blood pressure rose and pulse rate decreased. The bradycardia, presumably a reflex response to the rise in blood pressure, was generally most marked during the first 5 minutes, the heart rate returning toward control values when the infusion was continued at a constant rate. At the time when the maximal changes in oxygen consumption were observed, the mean decrease in pulse rate was 9 beats per minute. At that time systolic blood pressure had risen $36 \mathrm{~mm}$ and diastolic $26 \mathrm{~mm}$ of $\mathrm{Hg}$ above control levels.

A few patients reported headache or pounding in the head, and a few noted difficulty in "getting a deep breath" during the first few minutes of the infusion. These symptoms were transient, and most patients had no discomfort during the latter part of the infusion period. There were no other adverse reactions.
Because fear and anxiety can cause elevations of FFA and might lead to increases in oxygen consumption, we restudied patient C. H., a somewhat apprehensive individual, following the standard protocol but infusing only $0.85 \%$ sodium chloride. The usual control blood samples were taken, the Bowman pump was started, and the recording technician was told to mark "norepinephrine started" at that time. There were no changes of any significance in plasma FFA level or oxygen consumption (Table I, C. H., II). After a resting interval of 20 minutes, the same protocol was followed, this time with norepinephrine in the infusion. Both plasma FFA and oxygen consumption rose significantly.

Conversion of palmitate-1-C $C^{14}$ to $\mathrm{C}^{14} \mathrm{O}_{2}$. In two studies measurements of respiratory $\mathrm{C}^{14} \mathrm{O}_{2}$ were made before and during norepinephrine administration as shown in Table III. In both cases the net rate of production of $\mathrm{C}^{14} \mathrm{O}_{2}$ increased. The plasma FFA levels rose and the plasma FFA specific radioactivity fell at the same time. Thus the calculated minimal rate at which plasma FFA was being converted to $\mathrm{C}^{14} \mathrm{O}_{2}$ rose to a greater extent than would be indicated by considering the increase in absolute rate of $\mathrm{C}^{14} \mathrm{O}_{2}$ production alone. The changes in oxidation of plasma FFA calculated from concurrent measurements of FFA specific radioactivity in plasma and total $\mathrm{C}^{14} \mathrm{O}_{2}$ in respiratory gas represented increases of approximately $200 \%$ (Table III).

These calculations do not take account of the large size and relatively slow turnover of the body bicarbonate pool. This will introduce a lag between the time that stimulation of the rate of FFA oxidation in the tissues begins and the time when a new steady state rate of appearance of $\mathrm{C}^{14}$ in respiratory $\mathrm{CO}_{2}$ is attained. The measurements in the control period were made at least 30 minutes after starting the infusion of labeled palmitate. The $\mathrm{C}^{14} \mathrm{O}_{2}$ output in successive collections during the control period was very nearly the same, indicating that a steady state had been achieved, i.e., the specific radioactivity of the bicarbonate pool was relatively constant. The norepinephrine infusions, however, extended over a limited time period (14 and 17 minutes), and the specific radioactivity of the bicarbonate pool probably had not yet reached a new steady state level. Thus the estimated norepinephrine effects on the rate of 
TABLE III

Effects of norepinephrine on turnover and oxidation of serum FFA; modification by pronethalol treatment

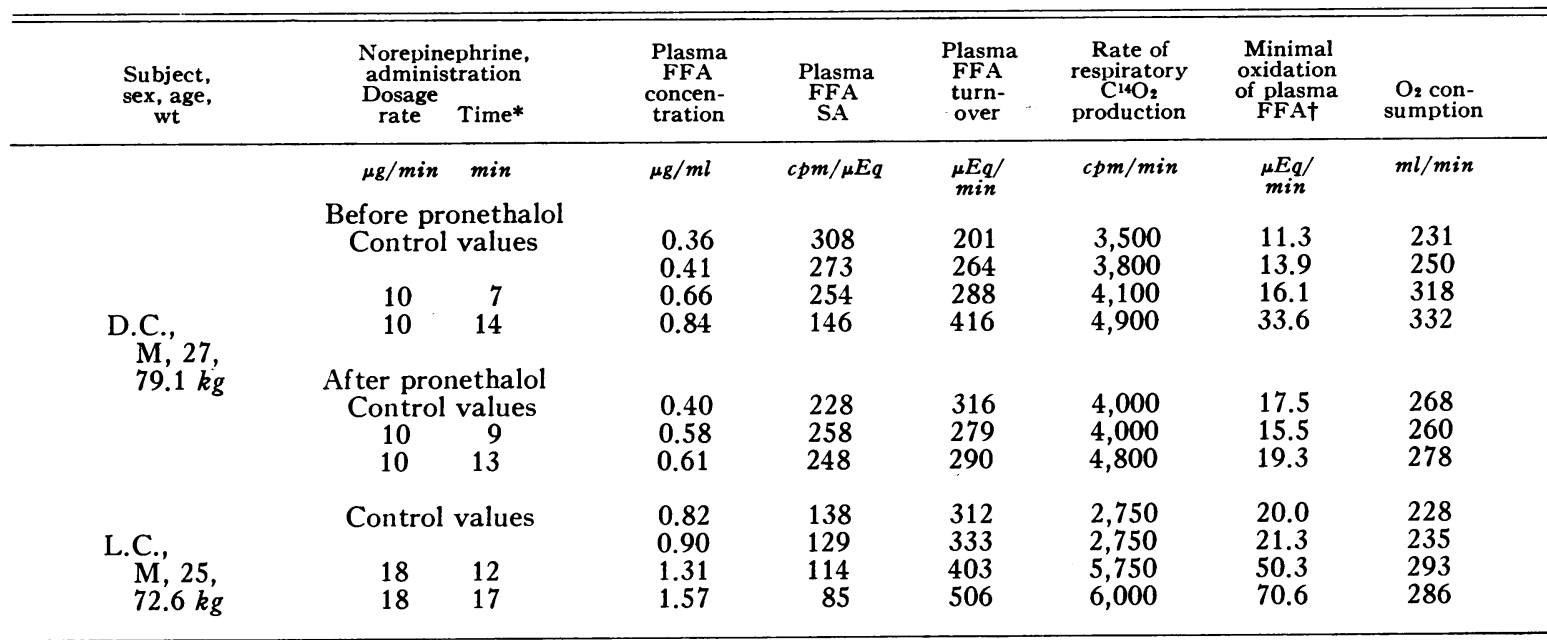

* Times indicate cumulative number of minutes from start of infusion at given dose rate.

+ Rate of production of respiratory $\mathrm{C}^{14} \mathrm{O}_{2}$ divided by mean specific radioactivity of serum FFA determined at start and at end of 4 -minute collection of respiratory $\mathrm{CO}_{2}$ (counts per minute/minute)/(counts per minute/microequivalent).

palmitate oxidation calculated in Table III may underestimate the magnitude of the true stimulation.

Effects of pronethalol. In six experiments pronethalol was given intravenously (75 to $100 \mathrm{mg}$ over a 10-minute period) after the rate of oxygen consumption had returned to control levels following discontinuing of the control norepinephrine infusion. A second infusion of norepinephrine was then given at the same dosage rate used in the first infusion, and the same parameters of response were measured (Tables II and III).

Pronethalol treatment did not materially alter the changes in pulse rate and blood pressure induced by norepinephrine. On the other hand, the rises in plasma FFA levels and the rises in rate of oxygen consumption were radically reduced or entirely abolished. The data from a representative experiment (Case B.L., I, in Table II) are presented graphically in Figure 1 . The rise in blood pressure and the slowing of the pulse rate were essentially the same with and without prior pronethalol treatment. In this case the sharp rise in plasma FFA level caused by norepinephrine was completely blocked by pronethalol treatment. The first norepinephrine infusion elevated the rate of oxygen consumption by almost $25 \%$. As in most of the other studies, the eleva-
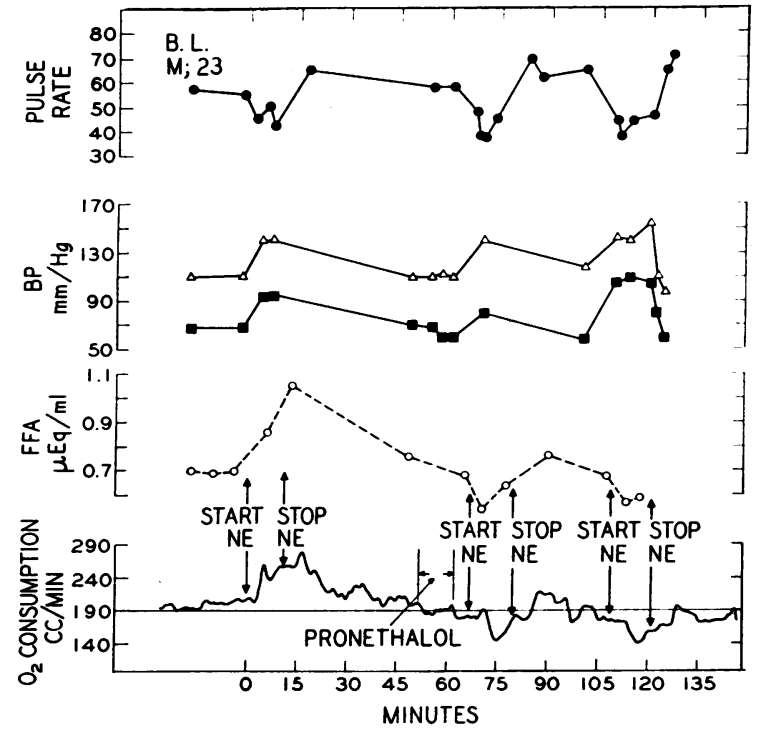

Fig. 1. EFFECTS OF NOREPINEPHRINE ON OXYGEN CONSUMPTION, PlASMA FFA LEVELS, BLOOD PRESSURE, AND PULSE RATE BEFORE AND AFTER ADMINISTRATION OF PRONETHALOL. Data from study of subject B.L. (I) (see Table II), a 23-year-old male weighing $66.1 \mathrm{~kg}$. Arrows indicate points at which norepinephrine infusion was begun (START NE) and ended (STOP NE). Pronethalol, $100 \mathrm{mg}$, was given intravenously over the 10 minute period indicated. Norepinephrine was infused at a rate of $16 \mu \mathrm{g}$ per minute during each of the three experimental periods, one before and the other two after pronethalol administration. 
tion persisted after the end of the infusion, and the return to basal levels was rather slow. In this study two infusions of norepinephrine were given after the administration of pronethalol. The rate of oxygen consumption, instead of rising, actually fell during these infusions and then showed some "rebound" above basal levels when the infusion was stopped. If the oxygen consumption during and after the norepinephrine infusion is integrated, the net change is close to zero.

In Tables II and III the responses are shown at the time of the peak in oxygen consumption during the control infusion of norepinphrine and then at the corresponding time during the postpronethalol infusion of norepinephrine. The "rebound" is not shown, but was noted in all cases and was in no case greater in relative magnitude than that shown in Figure 1. Plasma FFA levels fell during the postpronethalol infusion of norepinephrine in four of the six experiments. The levels then rose to values equal to or greater than control values when the norepinephrine infusion was stopped.

In five studies the changes in FFA turnover induced by norepinephrine were measured before and after administration of the blocker. Whereas the turnover was increased by norepinephrine given before pronethalol treatment, it was either not changed or actually fell when norepinephrine was given after pronethalol treatment.

These effects of pronethalol on the responses to norepinephrine are summarized in Table IV.

Changes in blood glucose and serum lactate. In four studies the blood glucose level was determined at 5- to 10-minute intervals. Control values were $83,86,92$, and $92 \mathrm{mg}$ per $100 \mathrm{ml}$; peak values, reached just at the end, or 5 to 10

TABLE IV

Effects of pronethalol on responses to norepinephrine

\begin{tabular}{lr}
\hline \hline & $\begin{array}{c}\text { Mean percent- } \\
\text { age change in- } \\
\text { duced by } \\
\text { norepinephrine }\end{array}$ \\
\cline { 2 - 2 } & $\begin{array}{c}\text { After } \\
\text { pron- } \\
\text { ethalol }\end{array}$ \\
\hline $\begin{array}{l}\text { Percentage change in FFA level [6]* } \\
\text { Percentage change in FFA turnover [5] }\end{array}$ & $\begin{array}{l}+100 \\
+71\end{array}$ \\
\hline
\end{tabular}

* Figures in brackets indicate number of studies summarized. minutes after the end of the norepinephrine infusion, were $94,100,104$, and $109 \mathrm{mg}$ per $100 \mathrm{ml}$, respectively. To test whether hyperglycemia per se might elevate metabolic rate, two of these four subjects were restudied in the metabolic chamber on another day. Glucose was given intravenously at a rapid rate, and blood glucose levels rose to well over $200 \mathrm{mg}$ per $100 \mathrm{ml}$. There was no measurable increase in oxygen consumption.

Plasma lactate levels were determined in three studies. Control values were $0.92,0.92$, and 1.00 ${ }_{\mu} \mathrm{Eq}$ per $\mathrm{ml}$; the peak values reached during norepinephrine infusion were $1.06,1.12$, and 1.01 $\mu \mathrm{Eq}$ per ml, respectively.

\section{Discussion}

In the present studies norepinephrine was shown to increase the rate of oxygen consumption in every subject tested. This calorigenic effect of norepinephrine has been demonstrated in several species of experimental animals (19-23). We are aware of only one previous report of positive results in man (24), however, although several investigators have reported no effect of norepinephrine on oxygen consumption in man (25-28). The calorigenic action of norepinephrine has been found to be smaller than that of epinephrine in rats (19), guinea pigs (20), and rabbits (21), and this is our experience in recent clinical studies (29). The results presented above, however, establish that under the conditions used norepinephrine has a significant calorigenic action in man.

With the rise in oxygen consumption there was a marked increase in the rate of fat mobilization manifested by an increase in concentration and rate of turnover of plasma FFA. Plasma FFA concentrations rose on the average by $127 \%$ and calculated turnover by $74 \%$. Conversion of palmitate-1-C $\mathrm{C}^{14}$ to $\mathrm{C}^{14} \mathrm{O}_{2}$ was simultaneously increased.

The question arises as to whether the rise in oxygen consumption, directly or indirectly, was a consequence of the FFA mobilization induced by norepinephrine. Pilkington, Lowe, Robinson, and Titterington (10) showed that pronethalol, a rather specific inhibitor of adrenergic receptors of the $\beta$ class $(8,9)$, blocked the FFA-mobilizing action of epinephrine. As shown here, the FFAmobilizing action of norepinephrine was similarly blocked. The associated rise in oxygen consump- 
tion, the calorigenic action, was also blocked. Preliminary studies have shown that the calorigenic action of epinephrine in man is likewise blocked by pronethalol (29). The concomitance of the two effects and the fact that both are blocked by pronethalol is compatible with, but does not establish, a cause and effect relationship between the FFA-mobilizing action and the calorigenic action of catecholamines. The catecholamines have many physiological activities in addition to their fat-mobilizing activity. The possibility that other catecholamine effects are more relevant to the calorigenic action and that these are simultaneously inhibited by pronethalol cannot be ruled out. At least, the fat-mobilizing action of the hormones and their activities relevant to the calorigenic effect are both blocked by pronethalol, and the receptors involved thus fall operationally into the category of $\beta$ receptors.

The degree to which FFA are diluted in pools of nonradioactive fatty acids after leaving the plasma and before being oxidized is not known. It is therefore not possible to draw firm conclusions regarding the rate at which fatty acids are being oxidized from data of the kind presented here. A minimal figure can be calculated by assuming no dilution, and as shown in Table III, such a calculation gives values only 5 to $10 \%$ that of the total turnover in the plasma compartment. Oxidation of this small amount of FFA would account for only a very small fraction of the observed oxygen consumption, either in the basal state or during administration of norepinephrine. It seems highly probable that there is considerable dilution by extravascular pools of fatty acids (nonesterified and esterified) and that the actual amounts being oxidized are much higher.

If the extra amount of FFA mobilized under the influence of norepinephrine does indeed represent the extra substrate being oxidized, it should be possible to correlate in some measure the observed increment in oxygen consumption with the amount of oxygen needed to oxidize the newly mobilized FFA. From the tabulated data, it can be calculated that in eight of the nine studies in which turnover was measured, the amount of oxygen needed to oxidize the extra FFA mobilized during norepinephrine administration equals or exceeds the observed increment in oxygen consumption.
(In the exceptional case [B.L., I, Table II], the response in FFA turnover was less than $25 \%$ of the next lowest response and only $10 \%$ of the response observed in the same patient given the same dose of norepinephrine on another occasion.) Two points should be considered in evaluating the significance of this relationship. First; as discussed above, we cannot be certain about the true extent to which the FFA turned over in the plasma compartment are being oxidized. Second, the absolute values for turnover by the constant infusion method may be too low. If there were any important re-entry of radioactive FFA from tissues into plasma, this would constitute an additional "input" of labeled material over and above that being infused and should be added to the value for "counts per minute infused per minute." The fact that a stable value for plasma FFA specific radioactivity is reached within 10 to 20 minutes indicates that any such tissue sources must quickly reach a plateau specific radioactivity. Still there might be considerable cycling into and out of a radioactive extravascular pool, and this turnover would go undetected. The fact that the absolute values for turnover obtained in the present study are in the same range as those obtained by Fredrickson and Gordon (30) using the single injection technique suggests that the potential error discussed cannot be large, but further studies are in progress to evaluate this. In any case, the true turnover would, if anything, be higher than that estimated here, and the extra substrate made available could, even if only partially oxidized, account for the observed increments in oxygen consumption.

Previous studies have shown that the rate of oxidation of labeled long-chain fatty acids by muscle and by liver in vitro is increased when their concentration in the incubation medium is increased (4-6). Recently, we have been able to demonstrate an increase in rate of oxygen utilization by perfused rat liver exposed to perfusing fluid containing a high concentration of FFA (7). The possibility that the calorigenic effect of the catecholamines and, by analogy, the hypermetabolism of the hyperthyroid state, are directly attributable to an increase in utilization of FFA made available to the peripheral tissues at high concentrations has been suggested (5). Earlier studies by Cori and Cori (31) led to the conclu- 
sion that the larger fraction of the extra caloric consumption after epinephrine administration was attributable to combustion of fat. Carlson and Hsieh have proposed that norepinephrine may be of great importance in the elevated heat production of cold-adapted animals $(32,33)$. Recent studies show that adipose tissue from cold-adapted rats releases FFA more rapidly than tissue from control rats $(34,35)$. Cold-adapted rats show an exaggerated calorigenic response to norepinephrine, and their adipose tissue appears to be more sensitive to the fat-mobilizing effects of norepinephrine (34-37). Thus there is considerable circumstantial evidence relating the elevated metabolic rate of rats exposed to cold to catecholaminestimulated fat-mobilization.

It is possible that the association between the FFA-mobilizing action and the calorigenic action of catecholamines is indirect, even though causally related. For example, the extra FFA made available may be converted to another substrate form before oxidation. The work of Havel and co-workers has shown that FFA are very rapidly incorporated into triglycerides in the liver and then resecreted in low-density lipoproteins (38). Studies by Gidez, Roheim, and Eder (39) and by Nestel and Steinberg (7) show that the output of triglycerides by the isolated perfused rat liver is increased when the FFA concentration of the perfusing fluid is elevated. It would be useful to know if the turnover of the triglycerides in lowdensity lipoproteins is increased by administration of catecholamines. A second possibility is that the FFA are first converted to ketone bodies in the liver and then further oxidized by peripheral tissues. The ketone body levels are indeed somewhat elevated during catecholamine administration to normal subjects (40). The increment in oxygen consumption may partly reflect the energy used for the breakdown and resynthesis of triglycerides within the adipose tissue, as proposed by Ball and Jungas (41), and the energy required for re-esterification of FFA mobilized and then taken up again in the liver and other tissues.

Lundholm showed that the calorigenic effect of epinephrine is well-correlated with the rise in serum lactate levels accompanying its administration and that infusion of lactate into rabbits induced a rise in oxygen consumption (21). In the present studies, with norepinephrine, there was little or no change in serum lactate levels. Brew- ster, Issacs, Osgood, and King found that epinephrine and norepinephrine had approximately equal calorigenic potency in dogs but, as in the present studies, norepinephrine did not raise serum lactate levels (23). The hyperglycemia accompanying epinephrine administration has also been proposed as a factor in the calorigenic response (1). Norepinephrine is much less potent than epinephrine in stimulating glycogenolysis, and at the dosages used in the present studies, there was only a minimal increase in blood glucose levels (maximal levels of 94 to $109 \mathrm{mg}$ per $100 \mathrm{ml}$ ). Intravenous administration of glucose at rates that raised blood glucose levels to values much higher than those reached during norepinephrine infusion (over $250 \mathrm{mg}$ per 100 $\mathrm{ml}$ ) did not cause any increase in oxygen consumption. Although hyperglycemia and hyperlacticacidemia may play some role in the hypermetabolic action of epinephrine, it seems unlikely that these play an important role in the calorigenic action of norepinephrine as used in the present studies.

Another factor that might contribute to the calorigenic action of norepinephrine is an increase in cardiac work. Since cardiac metabolism only accounts for about $5 \%$ of total body oxygen consumption in man (42), it seems unlikely that this could be increased enough to cause the increases in rate of oxygen consumption induced by norepinephrine in these studies. Moreover, pretreatment with pronethalol did not importantly modify the changes in blood pressure and pulse rate induced by norepinephrine, whereas it did abolish the rise in oxygen consumption.

\section{Summary}

Intravenous infusion of norepinephrine (0.13 to $0.31 \mu \mathrm{g}$ per $\mathrm{kg}$ per minute) significantly increased oxygen consumption in fasting young adults, the mean increase being $21 \pm 8 \%$ above control values in 11 studies. Concomitantly, plasma FFA levels rose $127 \pm 57 \%$ above control values, and turnover of plasma FFA rose $74 \pm 53 \%$. Blood glucose levels increased only very slightly (mean increase of $14 \mathrm{mg}$ per $100 \mathrm{ml}$ in four cases), and changes in plasma lactate levels were of marginal significance. In two cases conversion of palmitate-1-C $\mathrm{C}^{14}$ to $\mathrm{C}^{14} \mathrm{O}_{2}$ was measured and was shown to be increased 2 to 3 times by norepinephrine administration. 
When the subjects were given an intravenous dose of 75 to $100 \mathrm{mg}$ of pronethalol, a betaadrenergic blocking agent, before the norepinephrine infusion, the rise in oxygen consumption and the increase in FFA levels and turnover were radically reduced or entirely abolished. The changes in blood pressure and pulse rate were essentially the same as those observed in the absence of the blocking agent.

The present findings are compatible with the hypothesis that the calorigenic action of norepinephrine is causally related to its ability to increase the rate of FFA mobilization. This may be direct, reflecting an increased rate of utilization of the FFA themselves, or indirect, reflecting utilization of triglycerides or ketone bodies formed in the liver at an increased rate as a result of more rapid hepatic uptake of FFA. In addition, the increase in oxygen consumption associated with an increased turnover of fatty acids within the adipose tissue, as previously described, may contribute to the increase in over-all metabolic rate.

\section{References}

1. Griffith, F. R., Jr. Fact and theory regarding the calorigenic action of adrenaline. Physiol. Rev. 1951, 31, 151.

2. Ellis, S. The metabolic effects of epinephrine and related amines. Pharmacol. Rev. 1956, 8, 485.

3. Fredrickson, D. S., and R. S. Gordon, Jr. Transport of fatty acids. Physiol. Rev. 1958, 38, 585.

4. Fritz, I. B., D. G. Davis, R. H. Holtrop, and H. Dundee. Fatty acid oxidation by skeletal muscle during rest and activity. Amer. J. Physiol. 1958, 194, 379.

5. Eaton, P., and D. Steinberg. Effects of medium fatty acid concentration, epinephrine, and glucose on palmitate-1-C $\mathrm{C}^{\mathbf{1 4}}$ oxidation and incorporation into neutral lipids by skeletal muscle in vitro. J. Lipid Res. 1961, 2, 376.

6. Rose, H., M. Vaughan, and D. Steinberg. Utilization of fatty acids by liver slices as a function of medium concentration. Amer. J. Physiol. 1964, 206 , in press.

7. Nestel, P. J., and D. Steinberg. Fate of palmitate and of linoleate perfused through the isolated rat liver at high concentration. J. Lipid Res. 1963, 4, 461.

8. Black, J. W., and J. S. Stephenson. Pharmacology of a new adrenergic beta-receptor-blocking compound (Nethalide). Lancet 1962, 2, 311.

9. Dornhorst, A. C., and B. F. Robinson. Clinical pharmacology of a beta-adrenergic-blocking agent (Nethalide). Lancet 1962, 2, 314.

10. Pilkington, T. R. E., R. D. Lowe, B. F. Robinson, and E. Titterington. Effect of adrenergic block- ade on glucose and fatty-acid mobilisation in man. Lancet 1962, 2, 316.

11. Steinberg, D., P. J. Nestel, E. R. Buskirk, and R. H. Thompson. Relation between fat-mobilization and hypermetabolism induced by norepinephrine and triiodothyronine (abstract). J. clin. Invest. 1963, 42, 983.

12. Buskirk, E. R., R. H. Thompson, R. Moore, and G. D. Whedon. Human energy expenditure studies in the National Institute of Arthritis and Metabolic Diseases metabolic chamber. Amer. J. clin. Nutr. 1960, 8, 602.

13. Dole, V. P. A relation between non-esterified fatty acids in p'asma and the metabolism of glucose. J. clin. Invest. 1956, 35, 150.

14. Keston, A. S. Abstracts of papers, 129th Meeting of the Amer. Chem. Soc., April 1956, p. 31C.

15. Hohorst, H. J., F. H. Krentz, and T. Bucher. Uber Metabolitgehalte und Metabolit-konzentrationen in der Leber der Ratte. Biochem. Z. 1959, 332, 18.

16. Armstrong, D. T., R. Steele, N. Altszuler, A. Dunn, J. S. Bishop, and R. C. De Bodo. Regulation of plasma free fatty acid turnover. Amer. J. Physiol. 1961, 201, 9.

17. Borgström, B. Investigation on lipid separation methods. Separation of phospholipids from neutral fat and fatty acids. Acta physiol. scand. 1952, 25, 101.

18. Steinberg, D. A new approach to radioassay of aqueous solutions in the liquid scintillation spectrometer. Analyt. Biochem. 1960, 1, 23.

19. Thibault, O. Adrenaline et sympathine. Action de la nor-adrenaline sur la consommation d'oxygene du rat blanc. C. R. Soc. Biol. (Paris) 1948, 142, 47.

20. Lundholm, L. The effect of 1-noradrenaline and ergotamine on the oxygen consumption of guinea pigs. Acta physiol. scand. 1949, 18, 341.

21. Lundholm, L. The effect of 1-noradrenaline on the oxygen consumption and lactic acid content of the blood in the rabbit. Acta physiol. scand. 1950, 21, 195.

22. Bauer, G., and F. Lembeck. Die stoffwechselsteigernde Wirkung des Noradrenalins. NaunynSchmiedeberg's Arch. exp. Path. Pharmak. 195152, 214, 262.

23. Brewster, W. R., Jr., J. P. Issacs, P. F. Osgood, and T. L. King. The hemodynamic and metabolic interrelationships in the activity of epinephrine, norepinephrine, and the thyroid hormones. Circulation 1956, 13, 1.

24. Kroneberg, G., and G. Rönicke. Versuche mit Arterenol am Menschen. Klin. Wschr. 1950, 28, 353.

25. Goldenberg, M., K. L. Pines, E. de F. Baldwin, D. G. Greene, and C. E. Roh. The hemodynamic response of man to norepinephrine and epinephrine and its relation to the problems of hypertension. Amer. J. Med. 1948, 5, 792. 
26. Reale, A., A. Kappert, C. H. Skoglund, and G. C. Sutton. The effect of L-noradrenaline on the oxygen consumption of human beings. Acta physiol. scand. 1950, 20, 1953.

27. Becker, J., A. Bernsmeier, and W. Lorenz. Untersuchungen uber den respiratorischen Stoffwechsel des Menschen unter der Wirkung von Noradrenalin. Z. ges. exp. Med. 1952, 119, 617.

28. Whelan, R. F., and I. M. Young. The effect of adrenaline and noradrenaline infusions on respiration in man. Brit. J. Pharmacol. 1953, 8, 98.

29. Steinberg, D., R. P. Eaton, E. R. Buskirk, and R. H. Thompson. Unpublished data.

30. Fredrickson, D. S., and R. S. Gordon, Jr. The metabolism of albumin-bound $\mathrm{C}^{14}$-labeled unesterified fatty acids in normal human subjects. J. clin. Invest. 1958, 37, 1504.

31. Cori, C. F., and G. T. Cori. The mechanism of epinephrine action. II. The influence of epinephrine and insulin on the carbohydrate metabolism of rats in the postabsorptive state. J. biol. Chem. 1928, $79,321$.

32. Carlson, L. D. Nonshivering thermogenesis and its endocrine control. Fed. Proc. 1960, 19, 25.

33. Hsieh, A. C. L., and L. D. Carlson. Role of adrenaline and noradrenaline in chemical regulation of heat production. Amer. J. Physiol. 1957, 190, 243.

34. Wertheimer, E., M. Hamosh, and E. Shafrir. Fac- tors affecting fat mobilization from adipose tissue. Amer. J. clin. Nutr. 1960, 8, 705.

35. Mallov, S. Cold effects in rat: plasma and adipose tissue free fatty acids and adipose lipase. Amer. J. Physiol. 1963, 204, 157.

36. Depocas, F. Calorigenesis from various organ systems in the whole animal. Fed. Proc. 1960, 19, 19.

37. Hannon, J. P., and A. M. Larson. Fatty acid metabolism during norepinephrine-induced thermogenesis in the cold-acclimatized rat. Amer. J. Physiol. 1962, 203, 1055.

38. Havel, R. J., J. M. Felts, and C. M. Van Duyne. Formation and fate of endogenous triglycerides in blood plasma of rabbits. J. Lipid Res. 1962, 3, 297.

39. Gidez, L. I., P. S. Roheim, and H. A. Eder. Effect of plasma free fatty acid concentrations on triglyceride synthesis by the perfused liver. Fed. Proc. 1962, 21, 289.

40. Steinberg, D., R. P. Eaton, and S. Chernick. Unpublished results.

41. Ball, E. G., and R. L. Jungas. On the action of hormones which accelerate the rate of oxygen consumption and fatty acid release in rat adipose tissue in vitro. Proc. nat. Acad. Sci. (Wash.) 1961, 47, 932.

42. Levine, H. J., and R. J. Wagman. Energetics of the human heart. Amer. J. Cardiol. 1962, 9, 372.

\section{ANNOUNCEMENT OF MEETINGS}

The American Federation for Clinical Research will hold its Twenty-first Annual Meeting in Atlantic City, N. J., at the Casino Theater on the Steel Pier on Sunday, May 3, 1964, at 9:00 a.m. Joint sectional meetings with The American Society for Clinical Investigation will be held on Sunday afternoon at Chalfonte-Haddon Hall, and additional meetings sponsored by The American Federation for Clinical Research will be held on Sunday evening.

The American Society for Clinical Investigation, Inc., will hold its Fifty-sixth Annual Meeting in Atlantic City, N. J., on Monday, May 4, at 9:00 a.m., at the Casino Theater on the Steel Pier, and in simultaneous programs with The American Federation for Clinical Research on Sunday afternoon, May 3, in Chalfonte-Haddon Hall.

The Association of American Physicians will hold its Seventyseventh Annual Meeting in Atlantic City, N. J., at the Casino Theater on the Steel Pier on Tuesday, May 5, at 9:30 a.m., and in the Vernon Room, Chalfonte-Haddon Hall, on Wednesday, May 6, at 9:30 a.m.

The American Society for Clinical Nutrition will hold its Fourth Annual Meeting in Atlantic City, N. J., at the Colton Manor Hotel on Saturday, May 2, from 1:00 to 5:00 p.m. 